\title{
Online streaming public participation in forest management planning
}

\author{
Henn Korjus ${ }^{1,}{ }^{*}$, Priit Põllumäe ${ }^{1}$, Andres Kiviste ${ }^{1}$, \\ Ahto Kangur ${ }^{1}$, Diana Laarmann ${ }^{1}$, Risto Sirgmets ${ }^{1}$ and \\ Mait Lang ${ }^{1,2}$
}

\begin{abstract}
Korjus, H., Põllumäe, P., Kiviste, A., Kangur, A., Laarmann, D., Sirgmets, R., Lang, M. 2017. Online streaming public participation in forest management planning. - Forestry Studies | Metsanduslikud Uurimused 66, 5-13. ISSN 1406-9954. Journal homepage: http://mi.emu.ee/forestry.studies
\end{abstract}

\begin{abstract}
A new paradigm in forest management using a streaming input of public participation needs effective online solutions. The process should be real-time, secure, effective and efficient. People are expected to share their data and thoughts on forest management with forest owners for improving forest management and planning. The participatory approach supports communication within society and can be designed as an interactive web-based solution. Many pre-requisites have already been met and society is ready for a successful start of an interactive participatory forest planning system in Estonia. People use digital identification for various purposes and the state already maintains an online public forest register. Motivating people to participate in the planning process is always challenging yet important for the successful implementation of the system. The system should allow simulating the development and management of forest stands following the participatory input and using ecosystem models and economic calculations. The outputs from the system include management alternatives, risk assessments and financial reports. The system requires a reliable financial compensation scheme to ensure overall long-term stability of the system and agreements between interested persons or groups and forest owners.
\end{abstract}

Key words: forestry, participatory planning, forest owner, financial compensation, end-user.

Authors' addresses: ${ }^{1}$ Institute of Forestry and Rural Engineering, Estonian University of Life Sciences, Kreutzwaldi 5, 51014 Tartu, Estonia; ${ }^{2}$ Tartu Observatory, 61602 Tõravere, Tartu County, Estonia; *e-mail: henn.korjus@emu.ee

\section{Introduction}

In the modern society, most people are alienated from forests in their everyday life. However, there is still a general public demand for sustainable and excellent forestry practices. Therefore, forest policy has to standardize the variety of societies' expectations towards forest management during the formulation process (Krott, 2005). This is not an easy task as such standardizations occur on different levels. For example, there are at least three international forest policy initiatives currently launched on European Union or pan-European level (Edwards \& Kleinschmit, 2013). The standardization occurs also on an individual level in the form of decision-making as a choice between alternatives. Põllumäe et al. (2014) show how different values and objectives form the motivational decision-making aspects of private forest owners. However, there are institutional and situational aspects that influence the realization of a particular motive 
(Karppinen, 1998). Therefore, forest management policies are the result of continuously changing attitudinal aspects in the society with the varying power of various interest groups (Lindkvist et al., 2012).

Forest management aims at producing multiple services and benefits for the forest owner and the society. There are conflict situations inscribed in forest management and these are not just limited to conservation interests (Zachrisson \& Beland Lindahl, 2013). In the modern democracy, people are free to express their opinions and interests about anything, including the use of natural resources. However, if this input into forest policy results in long-term conflict situations it can create and increase distrust between the actors and therefore overall hinder the processes of resource use (Hellström, 2001). This makes forest management planning a very important tool in also public conflict management. Forest management planning could be used as a regulation mechanism that is able to give adequate feedback to the actors based on their own input and thus build its output on the constructive parts of the conflict (Raitio, 2013).

Transparency International (2017) defines open governance as "a concept that moves beyond the traditional notion of government and describes the relationships between leaders, public institutions and citizens, their interaction and decisionmaking processes". Estonia has been active in applying open governance concept in administrating different areas. It is evident that social actors should have more legal opportunities to participate in the process of managing forests in Estonia. This will promote better understanding between the actors and facilitate sustainable forestry.

In this concept paper, the approach of a real-time streaming input of public participation in forest management planning and feedback options are discussed. The basic principles and requirements of the system, system maintenance and interfacing with online data sources are the key elements for the successful implementation of such an interactive participatory forest management planning system (iPFS). The iPFS has first to be implemented at a regional or state level, since there are differences in the legislative environment, local traditions and data sources in different countries. Aiming at the universal solution is relevant in the long-term perspective as forest management issues become eventually more global.

\section{Background of the system}

Specific tools are required for public participation in forest management planning and nowadays these tools should be real-time, secure, effective and efficient. People tend to be enthusiastic to share their ideas about forest management but they usually lack time, knowledge and/or means to have direct communication with forest owners and managers. Consequently, political interest groups can take an advantage from such situations and influence political decisions in an inappropriate manner by distorting and amplifying the emotions of the public. Given the long history of forest resource management and its rational nature, it is difficult for resource managers and professionals to make sense of these emotions and use them in decision-making and planning processes (Buijs \& Lawrence, 2013). Often people do not have sufficient knowledge on the dynamics of forest ecosystems, so instead of future predictions they use memories from the not too distant past to describe the favourable status of an ecosystem. There is a conflict as forest ecosystems are constantly evolving and people do not seem to like the changes. The cultural background, urbanisation, past experiences and socio-demographic situation influence such interpretations about forests (Lindkvist et al., 2012). Ideally, active communication between the public and experts should solve the problem. People need adequate feedback on their ideas and thoughts about forest management, which forest owners will do most likely willingly to interested persons. 
Despite efforts to standardize environmental goals in order to sustain and extract different benefits, conflicts between various expectations exist. One approach for conflict solving is the decentralization of natural resource management by implementing a more participatory approach in forest policy and forest management planning. For example, Raitio (2012) has studied collaborative planning in the case of Finnish state forests and has concluded that both the regulatory (formal) and embedded (informal) institutions play key roles in collaborative planning. The presence of rational formal institutions does not make forest policy or planning legitimate by itself. Legitimacy of these processes comes with the understanding that certain decisions have been made right (Black, 2008). Such an understanding develops by participating, or at least knowing about the ways to participate.

Restrictions and additional requirements related to forest management decrease the income of forest owners and reduce the profitability of the forest property. For example, if a forest owner has legal temporary restrictions on getting income from tourism or berry picking because of protecting a NATURA2000 site, this should most likely be compensated by the state. However, as mentioned before, such forest management or forest use conflicts are not limited to biodiversity issues. These could just involve two private stakeholders with different interests towards a specific object. One of such examples could be berry harvesting in the case of open access ("everyman's right") to private lands. Sténs \& Sandström (2013) present one example from Sweden where the commercial berry-picking industry disturbs local landowners and communities. Surely, there are also reverse examples where e.g. landowners harvest in ways that limit or exclude the possibility of harvesting berries. Bringing together these different expectations means optimization that requires a reliable financial compensation scheme to ensure the long-term overall stability of the iPFS. It can be designed as a service provider/customer system where the customer pays or compensates for the lost revenue to the forest owner. The state can step into the system to compensate for or subsidise forest owners if the public is behind the customer's idea, i.e. when the potential conflicting interests are general public interests (e.g. biodiversity protection in urban areas). However, the system should be able to work also in more local contexts as described above (the case of berry picking).

The participatory approach in forest management planning can be designed as an interactive web- and GIS-based solution. Prerequisites for the interactive participatory planning system of forest management have already been met since people use digital identification in their everyday life and the state maintains a web-based openaccess forest register (e.g. in Estonia). The system should allow anyone using electronic identification to express his/her opinion about forest management in a specific area. The system simulates the development and management of forest stands as realistically as possible using updated ecosystem models and economic calculations. The outputs from the system are management alternatives, risk assessments and financial reports. The system should have powerful visualization tools, e.g. forested landscape visualization based on game engine software.

\section{System structure}

People should participate in forest management planning through a web-based interface and a functioning public register (Figure 1). Access should be guaranteed from different software platforms and devices, e.g. desktop computers, smartphones and portable devices, through the state portal (e.g. https:/ / www.eesti.ee) and/or the forest register (e.g. https:/ / register.metsad.ee). Administration and maintenance of such a participatory forestry information system is immense and should be safeguarded by the state.

The iPFS should motivate people to participate. Motivating people is always a 
challenge but an important prerequisite for the successful implementation of the iPFS. Many people are experienced and active in the virtual world. Social networks can serve as a basis for continuous inspiration and activation of people to participate in the iPFS. Wider problem-structuring may help to utilize the local, historically and culturally grounded practical knowledge in the iPFS as well as to reach higher commitment of local stakeholders. In addition, problemstructuring may have an important role in influencing the power balance between various stakeholder groups and administrative bodies (Khadka et al., 2013).

Public input to the iPFS is needed to be georeferenced and linked to other relevant public databases. This enables automatic identification of related forest properties and persons (forest owners, experts, etc.) at whom comments or requests will be immediately directed. Geographical referencing of the input data can be problematic if the iPFS does not include relevant maps, satellite images and aerial photographs assisting iPFS users to specify the forest locations involved. Holmgren \& Thuresson (1997) showed that dynamic forest management units can be treated as spatially continuous. There are already systems like Google Earth and NASA WorldView available for free public use; these should be linked into the iPFS and all additional data sources should complement the iPFS.

Several public registers have restrictions on public use due to containing sensitive data about people, protected species, etc. This information can still be useful for users to understand different management options and restrictions. So the iPFS needs trusted experts providing sensitive information in an acceptable way. This can be done by the state authorities or by forest management planning companies. So the iPFS should have links to consultancy services of forest owners (e.g. regional private forest owners associations or regional forestry consultants).

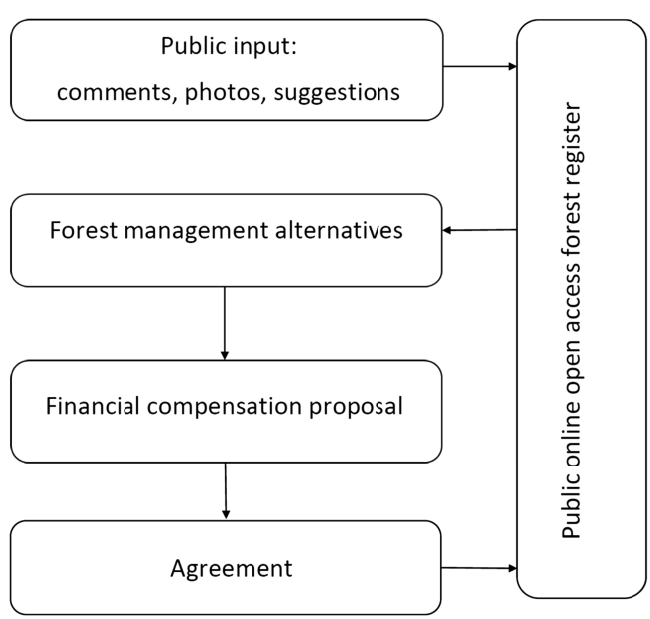

Figure 1. Generalized scheme of the iPFS. Public input is directed to the forest register which links the input with forest data and forest owners, and generates forest management alternatives. These alternatives serve as a basis for financial compensation calculations and an agreement proposal between system users and forest owners. The agreements reached are stored in the forest register. Also public input should be stored in the forest register.

Joonis 1. iFPS-i üldine skeem. Avalikkuse poolt antav sisend suunatakse metsaregistrisse, kus saadud infole lisatakse metsanduslikud andmed ja metsaomaniku andmed ning genereeritakse alternatiivsed metsa majandamise võtted. Need alternatiivid on metsaomanikule rahalise kompensatsiooni arvutamise ning süsteemi kasutajate ja metsaomanike vaheliste kokkulepete ettepanekute aluseks. Saavutatud kokkulepped säilitatakse metsaregistri juures. Samuti säilitatakse metsaregistri juures avalikkuse poolt antud sisend.

Smartphones and portable devices are powerful tools fostering immediate public participation in forest management. A photograph or video attributed with comments and GPS coordinates is quite a reliable data source for enhanced forest management planning. Different forestry apps should include the functionality of direct linking to the system. There are apps already for forest measurements and this information might be also useful for planning. Getting 
more information into the planning process enables increasing the quality of the output. Landowners will benefit from obtaining new ideas and have more information about their forests.

The users of the iPFS cannot be anonymous, proper user identification and authorisation gives trust and reliability to the system. The users can have different roles in the iPFS, e.g. the general public, landowner, entrepreneur, etc. The iPFS should include the internal component of ranking of users based on their knowledge, experience and previous activities in the system. There should be built-in blocking mechanisms avoiding abuse of the iPFS. System input could be extensive and therefore public comments and requests should expire or be archived within a certain time limit if no response follows the input.

In addition to the state authorities, the iPFS should have links to forest planning companies, the forest industry, universities, landowner organisations, environmental NGOs and forest certification. Specific problems have to be directed to experts who carry out tailored analysis. This cannot be done only on a voluntary basis as some analysis might need substantial financial resources.

\section{Modelling toolbox in the iPFS}

The iPFS should be designed capable and powerful enough to analyse the most common problems and predict forest development under different management scenarios. It should have built-in functionality for modelling of stand dynamics, species habitats, non-wood products and other services of a forest ecosystem. Models always have a certain level of abstraction because they create a system which is less complex than the reality, but models are still able to describe the processes in the real world. Models are presented in different forms, including conceptual and graphical models, statistical models and computer simulation tools (Kimmins, 1987). A variety of different tools makes the iPFS more attractive for the enduser. However, it is unrealistic to assume that there exists a single model that would be able to fulfil all the requirements for the different management purposes (Hynynen et al., 2002).

Model development is often based on a systems-analytical approach. Problems must be clearly formulated and modelling should be based on these three criteria: simplicity, observability and the biological realism of a model. Data collection is usually expensive and time-consuming, and therefore modelling efforts are limited by data constraints. If models are applied on a larger scale or to a longer time period than what they were calibrated for, this can have a major impact on the reliability of the expected output (Sims et al., 2009).

Every modelling project should include a model validation and evaluation part. Any model should be based on the best available knowledge and data to ensure reliability, therefore validation is a continuous process. An important objective in ecosystem modelling is to maintain the biological realism of the output. This may require procedures or experiences which are not always rigorously tested by typical statistical validation procedures. Scenario simulations are important for evaluating and testing the reliability and realism of model output, even if adequate test data sets are not available.

The iPFS should be linked to the database of forest models as the selection of a specific model depends on the problem that needs solving. ForMIS (http:/ / formis. emu.ee) is designed for handling and sharing scientific data and models in forest research and for attracting data users from different disciplines to do interdisciplinary research on forest ecosystems (Kiviste et al., 2015). ForMIS enables professional data storage and management of Estonian longterm forest research plots. In addition to research data, ForMIS system includes three databases of models: (1) forest growth and yield tables; (2) dendrometric formulas and (3) forest growth functions. Considering end-user needs for modelling the ForMIS 
data can be successfully used in deriving or testing general theoretical concepts and validation and comparison of various forest models (Eastaugh et al., 2013). The iFPS should generate powerful motivation for improving, commenting and selecting the models in ForMIS.

Different information demands may require temporal and spatial scaling. Scaling is part of the formal problem and addresses the fact that information becomes an emerging property at a certain temporal and spatial scale. If the level of scaling is wrongly defined, important effects might be masked as the noise hides the signal or the generalisation is too broad. While problem-setting is often a function of end-user demand, the quality of results should be independent of the end-user. If the need for information changes the temporal and spatial scaling resolution, it must be reassessed to ensure that the specified level meets the new enduser requirements.

A modelling toolbox of such a participatory system needs tools for evaluating the input provided by the system users and its effect on forest management planning and planned forest management actions. This can be achieved by combining system visualisation and risk assessment methods. A risk involved in forest ecosystems has been defined as the expected loss due to a particular hazard/disturbance in a given area and reference period (United Nations, 1992). Typically in forestry literature after defining the risk, the three following explanations are given: i) what risk assessment is; ii) how it is related to risk evaluation and iii) how all this sets together into risk management. Following the risk definition, risk assessment has been viewed as the procedure for quantifying risk by the potential of damage (Gadow, 2000). Then risk evaluation is seen as the economic evaluation of potential threats. And risk management is the set of strategies and actions for reducing the risk of damage. The system can include such a classical concept for analysing post-disturbance practical management actions. But it can also be used as a tool for assessing the pre-disturbance conditions and their vulnerability towards particular disturbances or management actions, aiming at reducing the sites' vulnerability towards similar actions in future.

End-user feedback on the modelling process will generate a constant need for additional models and model improvements. Modellers can view the iPFS as a large-scale testing arena of different tools and models. It is evident that a full implementation of such a complex system need a preceding legislative assessment for legally allowing a creation of links between different datasets and state information systems. Nevertheless, such an assessment cannot be made before the technical layout of the system is fixed.

\section{Economic calculations, system output and agreements}

The iPFS should include the module of economic calculations for implementing a fair financial mechanism to ensure agreements between system users and service providers. It is easy to understand that restricting forest use, e.g. timber production or berry picking creates lost revenue for the forest owner. If such a restriction benefits a few individuals, then it is seen as a service provided and these individuals should compensate for the lost revenue to the forest owner. If society overall benefits from such restrictions then it is correct to see this as a public good and to compensate for the lost revenue by the state. The iPFS should have functionality to discuss financial matters also with the state if there is a larger public interest present or state forests are involved. The financial compensation mechanism serves also as a filter of public input helping to identify reliable comments and data in the iPFS.

Forests offer a wide range of benefits. Among them the monetary value of timber sales is still the most easily calculable and understandable. For this reason the potential stumpage value from timber sales (net present value) should be taken as the basis 
for financial negotiations between forest owners and potentially interested persons/ society. A decrease in the stumpage value of timber sales reflects the opportunity cost for the forest owners implementing alternative management targets (Schröter et al., 2014). In this way the iPFS creates a real market for goods and services which have not been traded in reality until this moment, e.g. nature protection, nature-based tourism, etc. In addition, the outcome of the iPFS could be valuable for assessment of the societal demand for different goods and services from the forests and reflected in the real market situation. On a large scale, the iPFS provides an opportunity to manage our resources in the most economical and sustainable way while maximizing the net value of forests.

The iPFS should be able to interpret user comments and automatically translate them into management rules and activities. Automatic interpretation should be assisted by expert interventions to secure correct interpretation mostly in unprecedented situations. This could however delay responses from the iPFS and make the system inconvenient for users. Another approach can be that system users define the management rules by themselves making predefined choices, but a shortcoming in that may stem from users lacking knowledge to do this properly. So unexperienced users might seek for assistance anyway and accept delays willingly. A predefined choice should be a continuously updated set of samples that should be linked with relevant forest models.

The need for participation and communication in decision processes strongly relates to aspects of decision analysis. Decision-making not only requires quantitative facts and data but also information about the values, criteria and objectives in forest management (Wolfslehner \& Seidl, 2010). According to Nordström et al. (2010) the problem analysis can be designed as a fivestage process in multi-criteria decision analysis (Figure 2). The alternative forest management activities are generated from the new rules for the target area. This is a basis for calculation of the "fair price" as a difference between two management regimes in the area. This price serves as a starting point for negotiations between customers and forest owners. Agreement should be based on market prices and ensure that both parties benefit from this. However, some agreements may be reached without financial compensation for a forest owner. The agreements should be stored in the forest register to ensure their validity. The system should remember also the cases when agreement is not reached as this might be still useful information for the planning process in the future. The role of an optimization procedure is to propose and support decisions at a landscape and/or ownership level. Linear programming, heuristics and other methods are available for this.

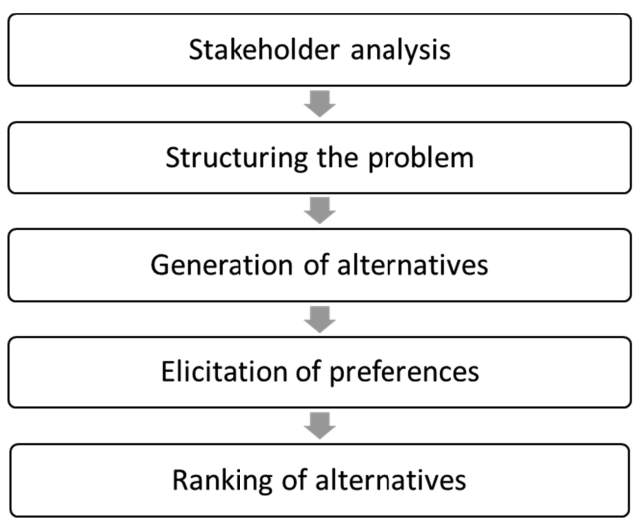

Figure 2. Generalized scheme of a five-stage process (Nordström et al., 2010) for the participatory multi-criteria decision analysis.

Joonis 2. Kaasava mitmekriteeriumilise analüüsi kui viieetapilise protsessi (Nordström et al., 2010) üldine skeem.

The iPFS should have a built-in ability to generate the most common reports about forest resources (areas, distributions, etc.) and planned activities. GIS tools enable creating thematic maps. The variety of iPFS outputs should be based on a powerful report generator. Visualization is also a powerful tool to communicate the iPFS 
output. Visualization tools like the SVS (http:// forsys.cfr.washington.edu/svs. $\mathrm{html}$ ) enable generating realistic views on forests from different perspectives and also visualizing changes/activities on forested landscape. Airborne laser scanning (ALS) can provide background data for the economic analysis and forest visualization. Single tree detection combined with breast height diameter and height facilitates realistic output and decisions.

\section{Conclusions}

Participatory planning supports communication within society and enhances forest management options. Motivating people to participate in the planning process is always challenging yet important for the successful implementation of the participatory system. The tools for participatory planning should be designed as an online interactive solution to ensure easy and secure access and involvement of people.

New legal opportunities should support social actors to participate in the process of managing forests in Estonia. It should be acknowledged that restrictions and requirements on forest management decrease the income of forest owners as well as dealing with the environmental and social concerns improves the sustainability of forest management.

A new paradigm in forest management using a real-time streaming input from public participation has many pre-requisites which have been met for implementation in Estonia. The system should allow simulating the development and management of forest stands according to the participatory input to the forest register. The output from the system includes management alternatives, risk assessment and financial reports. The system requires a reliable financial compensation scheme to ensure agreements between system users and forest owners. Scientific knowledge and research can continuously support the participatory forest management approach with new advances, solutions and data. We presume that the benefits of the iPFS prove much greater than the costs of establishing and maintaining the system.

Acknowledgements. This research is partly connected to the project 'The carbon dynamics in Estonian forests affected by sustainable management' (Estonian Ministry of Education and Research grant IUT21-4).

\section{References}

Black, J. 2008. Constructing and contesting legitimacy and accountability in polycentric regulatory regimes. - Regulation \& Governance, 2(2), 137-164.

Buijs, A., Lawrence, A. 2013. Emotional conflicts in rational forestry: Towards a research agenda for understanding emotions in environmental conflicts. - Forest Policy and Economics, 33, 104-111.

Eastaugh, C.S., Kangur, A., Korjus, H., Kiviste, A., Zlatanov, T., Velichkov, I., Srdjevic, B., Srdjevic, Z., Hasenauer, H. 2013. Scaling issues and constraints in modelling of forest ecosystems: a review with special focus on user needs. - Baltic Forestry, 19(2), 316-330.

Edwards, P., Kleinschmit, D. 2013. Towards a European forest policy - conflicting courses. - Forest Policy and Economics, 33, 87-93.

Gadow, K. v. 2000. Evaluating risk in forest planning models. - Silva Fennica, 34(2), 181-191.

Hellström, E. 2001. Conflict cultures - qualitative comparative analysis of environmental conflicts in forestry. - Silva Fennica Monographs, 2, 109 pp.

Holmgren, P., Thuresson, T. 1997. Applying objectively estimated and spatially continuous forest parameters in tactical planning to obtain dynamic treatment units. - Forest Science, 43(3), 317-326.

Hynynen, J., Ojansuu, R., Hökkä, H., Siipilehto, J., Salminen, H., Haapala, P. 2002. Models for predicting stand development in MELA system. - Metsäntutkimuslaitoksen tiedonantoja, 835, $116 \mathrm{pp}$.

Karppinen, H. 1998. Values and objectives of non-industrial private forest owners in Finland. - Silva Fennica, 32, 43-59.

Khadka, C., Hujala, T., Wolfslehner, B., Vacik, H. 2013. Problem structuring in participatory forest planning. - Forest Policy and Economics, 26, 1-11.

Kimmins, J.P. 1987. Forest ecology: models and the role in ecology and resource management. Macmillan Publishing Company, New York, 460-474.

Kiviste, A., Hordo, M., Kangur, A., Kardakov, A., Laarmann, D., Lilleleht, A., Metslaid, S., Sims, A., Korjus, H. 2015. Monitoring and modeling of forest ecosystems: the Estonian Network of Forest Research Plots. - Forestry studies / Metsanduslikud uurimused, 62, 26-38. 
Krott, M. 2005. Forest policy analysis. Berlin/Heidelberg: Springer-Verlag. 323 pp.

Lindkvist, A., Mineur, E., Nordlund, A., Nordlund, C., Olsson, O., Sandström, C., Westin, K., Keskitalo, E.C.H. 2012. Attitudes on intensive forestry. An investigation into perceptions of increased production requirements in Swedish forestry. - Scandinavian Journal of Forest Research, 27(5), 438-448.

Nordström, E.-M., Eriksson, L.O., Öhman, K. 2010. Integrating multiple criteria decision analysis in participatory forest planning: Experience from a case study in northern Sweden. - Forest Policy and Economics, 12(8), 562-574.

Põllumäe, P., Korjus, H., Paluots, T. 2014. Management motives of Estonian private forest owners. - Forest Policy and Economics, 42, 8-14.

Raitio, K. 2012. New institutional approach to collaborative forest planning on public land: Methods for analysis and lessons for policy. - Land Use Policy, 29(2), 309-316.

Raitio, K. 2013. Discursive institutionalist approach to conflict management analysis - The case of oldgrowth forest conflicts on state-owned land in Finland. - Forest Policy and Economics, 33, 97-103.

Schröter, M., Rusch, G.M., Barton, D.N., Blumentrath, S., Nordén, B. 2014. Ecosystem services and opportunity costs shift spatial priorities for con- serving forest biodiversity. - PLOS ONE, 9(11), e112557.

Sims, A., Hordo, M., Kangur, A., Kiviste, K., Jõgiste, K., von Gadow, K. 2009. Tracking disturbances induced changes in stand development on irregular measurement intervals in the Järvselja forest experiments. - Baltic Forestry, 15(2), 151-160

Sténs, A., Sandström, C. 2013. Divergent interests and ideas around property rights: The case of berry harvesting in Sweden. - Forest Policy and Economics, 33, 56-62.

Transparency International 2017. Open governance. [WWW document]. - URL http://www.transparency.org.uk/our-work/uk-corruption/opengovernance/ [Accessed 28 April 2017].

United Nations. 1992. Internationally agreed glossary of basic terms related to disaster management. United Nations Department of Humanitarian Affairs, Geneva.

Wolfslehner, B., Seidl, R. 2010. Harnessing ecosystem models and multi-criteria decision analysis for the support of forest management. - Environmental Management, 46(6), 850-861.

Zachrisson, A., Beland Lindahl, K. 2013. Conflict resolution through collaboration: Preconditions and limitations in forest and nature conservation controversies. - Forest Policy and Economics, 33, 39-46.

\section{Veebipõhine avalikkust kaasav metsakorraldus}

\section{Henn Korjus, Priit Põllumäe, Andres Kiviste, Ahto Kangur, Diana Laarmann, Risto Sirgmets ja Mait Lang}

\section{Kokkuvõte}

Avalikkuse veebipõhine aktiivne kaasamine metsamajanduslike tegevuste kavandamisprotsessidesse vajab tõhusat lahendamist. Kaasamine peab olema reaalajas toimuv, turvaline ja efektiivne. Inimesed peaksid saama metsaomanikule väljendada oma huvisid ja mõtteid konkreetsete metsaosade majandamise kohta. Kaasav lähenemine soodustab ühiskonnasisest suhtlemist ja üheskoos sobivate lahenduste leidmist. Eestis on olemas eeldused sellise interaktiivse metsakorraldusliku süsteemi edukaks käivitamiseks: inimesed kasutavad digitaalset identifitseerimist ja riik peab avalikult ligipääsetavat metsaregistrit. Kaasamise infosüsteem peab olema piisavalt võimekas, et sisemiselt modelleerida metsamajandus- likke tegevusi vastavalt süsteemi kasutajate soovidele. Süsteemi väljunditeks on metsa majandamise alternatiivid, riskihinnangud ja majanduslikud arvutused. Süsteem peab sisaldama usaldusväärset mehhanismi metsamajanduslike piirangute tõttu metsaomanikul saamata jääva tulu või tekkiva kahju väljaarvutamiseks ning kompenseerimiseks, et tagada kogu süsteemi stabiilne ja efektiivne toimimine. Saavutatud kokkulepped süsteemi kasutajate ja metsaomanike vahel tuleks säilitada metsaregistri juures. Veebipõhisest avalikkust kaasavast metsakorralduse süsteemist saadav kasu on tõenäoliselt suurem kui kulud sellise süsteemi loomiseks ja käigushoidmiseks. 